\title{
PERSPEKTIF FILSAFAT PENDIDIKAN TERHADAP PSIKOLOGI PENDIDIKAN HUMANISTIK
}

\author{
Fadhil Hikmawan \\ Fakultas Filsafat Universitas Gadjah Mada \\ fadhil_hikmawan@rocketmail.com
}

\begin{abstract}
Abstrak
Tujuan ditulisnya perspektif filsafat pendidikan terhadap psikologi humanistik adalah untuk mendeskripsikan secara kritis perspektif filsafat pendidikan yang ada dalam psikologi pendidikan humanistik. Metode dalam kajian ini adalah penelitian kepustakaan. Data dalam penelitian ini adalah buku dan jurnal yang relevan dengan filsafat, filsafat pendidikan, dan psikologi pendidikan humanistik. Teknik analisis dalam kajian ini adalah analisis tematik. Hasil penelitian menunjukkan filsafat pendidikan psikologi pendidikan humanistik adalah filsafat pendidikan yang memandang pendidikan sebagai proses memanusiakan peserta didik sehingga mampu berkembang dan beraktualisasi diri dengan segenap potensi asli yang ada dalam dirinya.
\end{abstract}

Kata-kata kunci: filsafat pendidikan, psikologi pendidikan, humanistik.

Pada artikel ini dideskripsikan tentang filsafat pendidikan dalam aliran psikologi pendidikan humanistik. Deskripsi filsafat pendidikan dalam aliran psikologi pendidikan humanistik berisi tentang pengertian dan cabang-cabang dari filsafat, filsafat pendidikan, dan filsafat pendidikan dalam aliran psikologi pendidikan humanistik.

Psikologi humanistik adalah salah satu dari tiga aliran klasik dalam psikologi, selain aliran psikologi behavioristik dengan tokohnya John B. Watson dan aliran psikologi psikonanalis dengan tokohnya Sigmund Freud. Aliran psikologi pendidikan humanistik adalah aliran psikologi yang sangat menjunjung tinggi kemanusiaan manusia yang unik dan memiliki potensi-potensi individu yang baik. Aliran ini banyak memperoleh pengaruh dari aliran filsafat humanistik dengan tokoh J.J. Rousseau dan aliran eksistensialisme dengan tokohnya J.J. Sartre (Saifulah, 1983). Selain diterapkan dalam bidang psikologi konseling, psikologi industri dan organisasi, dan psikologi klinis, perkembangan aliran psikologi humanistik diterapkan pula dalam bidang pendidikan. Penerapan psikologi humanistik dalam bidang pendidikan lazim disebut dengan istilah psikologi pendidikan humanistik.

Berdasar rasional bahwa setiap aliran psikologi, termasuk psikologi pendidikan, memiliki dasar filsafat maka dalam aliran psikologi pendidikan humanistik pada penelitian ini dideskripsikan secara kritis tentang dasar filsafat pendidikan yang ada dalam aliran psikologi pendidikan humanistik.

\section{METODE}

Metode dalam kajian ini adalah penelitian kepustakaan (library research). Alat pengumpulan data dalam penelitian ini adalah dokumen. Data dalam penelitian ini adalah buku dan jurnal yang relevan dengan filsafat, filsafat pendidikan, dan psikologi pendidikan humanistik. Teknik analisis data dalam kajian ini adalah analisis tematik.

\section{HASIL DAN PEMBAHASAN}

\section{Filsafat Pendidikan}

\section{Filsafat}

Sebelum menuju pada arti filsafat pendidikan maka terlebih dahulu dideskripsikan pengertian filsafat. Filsafat adalah disiplin yang mempelajari objek-objek kemanusiaan secara menyeluruh (komprehensif), merangkum, spekulatif rasional, dan mendalam sampai ke akarnya (radiks), sehingga diperoleh inti hakiki dari objek yang dipelajari (Hanurawan, 2012). Masalah-masalah kemanusiaan utama dalam 
hidup ini meliputi 3 hubungan penting manusia dalam kehidupannya, yaitu:

- Hubungan manusia dengan keberadaan Tuhan.

- Hubungan manusia dengan keberadaan alam semesta.

- Hubungan manusia dengan keberadaan manusia, baik secara individual maupun kelompok.

Seorang tokoh filsafat pendidikan Indonesia, Barnadib (1994) menjelaskan filsafat sebagai pandangan yang menyeluruh dan sistematis. Filsafat bersifat menyeluruh karena filsafat bukan hanya pengetahuan, melainkan juga suatu pandangan yang dapat menembus sampai di balik pengetahuan itu sendiri. Filsafat bersifat sistematis karena filsafat menggunakan berpikir secara sadar, teliti, dan teratur sesuai dengan hukum-hukum yang ada.

\section{Cabang-Cabang filsafat}

Cabang-cabang filsafat yang utama adalah sebagai berikut :

- Metafisika (ontologi). Metafisika adalah cabang filsafat yang mempelajari hakekat realitas terdalam dari segala sesuatu, baik yang bersifat fisik maupun yang bersifat non fisik.

- $\quad$ Epistemologi adalah cabang filsafat yang melakukan penelaahan tentang hakekat pengetahuan manusia. Secara khusus, dalam epistemologi dilakukan kajian-kajian yang mendalam tentang hakekat terjadinya perbuatan mengetahui, sumber pengetahuan, tingkat-tingkat pengetahuan, metode untuk memperoleh pengetahuan, kesahihan pengetahuan, dan kebenaran pengetahuan.

- Aksiologi adalah cabang filsafat yang mempelajari hakekat nilai. Berdasar pada pokok penekanannya, aksiologi dapat dibagi menjadi etika (filsafat tentang baik buruk perilaku manusia) atau filsafat moral dan estetika atau filsafat keindahan.

Selain cabang-cabang utama filsafat di atas,masih terdapat cabang-cabang filsafat lain yang bersifat khusus. Cabang filsafat khusus itu antara lain adalah: filsafat manusia, filsafat ketuhanan, filsafat alam (kosmologi), filsafat agama, filsafat sosial dan politik, filsafat seni, filsafat politik, filsafat ekonomi dan filsafat pendidikan (Hanurawan, 2012).

\section{Filsafat Pendidikan}

Filsafat pendidikan adalah cabang filsafat yang mempelajari hakekat pendidikan Filsafat pendidikan memandang kegiatan pendidikan sebagai objek yang perlu dikaji. Ada banyak defisini mengenai filsafat pendidikan pada tetapi akhirnya semua berpendapat dan mengajukan soal kaidah-kaidah berpikir filsafat dalam rangka menyelesaikan masalah-masalah yang ada dalam bidang pendidikan.

Upaya ini kemudian menghasilan teori dan metode pendidikan untuk menentukan gerak semua aktivitas pendidikan. Studi filosofis yang sangat luas dan mendalam tentang pendidikan itu pada dasarnya mencakup kajiankajian sebagai berikut:

- Hakikat pendidikan

- Tujuan pendidikan

- Hakekat pengajaran dan belajar

- Bagian-bagian pendidikan

- $\quad$ Ruang lingkup pendidikan

- Hubungan pendidikan dengan kehidupan (manusia, etika, nilai, moral, estetika).

Dalam konteks yang bersifat mendesak dalam kehidupan individu, Hanurawan dkk. (2006) menjelaskan bahwa pendidikan memegang fungsi dan peran penting bagi kehidupan seseorang. Selanjutnya Hanurawan dkk. (2006) menjelaskan bahwa dilihat dari sejarah, manusia dapat dikatakan sebagai homo educandum, artinya adalah makhluk yang dapat dididik, mendidik dan perlu pendidikan. Dikatakan dapat dididik karena tingkah lakunya dapat diubah ke arah yang lebih baik. Orang yang terdidik memiliki kesadaran untuk selalu mengubah perilakunya ke arah yang lebih baik.

Apabila ditelaah secara lebih mendalam filsafat pendidikan merupakan salah satu cabang filsafat maka dapat dikemukakan bahwa dasardasar berpikir dalam melakukan perenungan filsafat pendidikan harus mengacu pada dasardasar filsafat yang utama, yaitu :

- Dasar metafisika (ontologi) dalam bidang pendidikan

Metafisika adalah cabang filsafat yang berkaitan dengan proses analitis atas hakikat 
fundamental mengenai keberadaan dan realitas terdalam dari sesuatu. Secara umum topik analisis metafisika dalam pendidikan meliputi kajian tentang eksistensi pendidikan, karakteristik pendidikan, hakekat ruang dan waktu dalam pendidikan, kausalitas dalam pendidikan, dan materialisme dan spiritualisme dalam pendidikan. Dalam bidang pendidikan, metafisika sebagai dasar adalah yang terkait dengan objek yang dapat ditemui dalam keberadaan aliran-aliran besar pendidikan. Aliran-aliran besar dalam pendidikan dapat ditemui dalam aliran pendidikan yang bersifat tingkah laku sebagai hasil dari sebuah pengalaman (behavioristik) yang menganut paham monisme materialistik dan aliran pendidikan yang bersifat transpersonal yang bersifat monisme transpersonal.

- Dasar epistemologi dalam bidang pendidikan

Epistemologi adalah cabang filsafat yang berkaitan dengan asal, sifat, karakter dan jenis pengetahuan. Epistemologi adalah sebuah cabang filsafat yang merujuk pada sebuah pengertian bahwa sebuah pengetahuan harus kriteria dasar bagi standar penentuan suatu kebenaran pengetahuan. Topik ini termasuk salah satu yang paling sering diperdebatkan dan dibahas dalam bidang pendidikan, misalnya bagaimana metode dalam pendidikan dan pengajaran? bagaimana pengetahuan yang sahih dalam bidang pendidikan? dan bagaimana dan apa ruang lingkup pengetahuan atau kompetensi dalam bidang pendidikan?

- Dasar Aksiologi dalam bidang pendidikan

Aksiologi merupakan cabang filsafat ilmu yang mempertanyakan bagaimana dasar aksiologi dalam bidang-bidang pendidikan, seperti dalam pembuatan tujuan pendidikan, kurikulum pendidikan, dan metode pendidikan. Dasar aksiologi dalam pendidikan meliputi dasar etika dan estetika dalam bidang pendidikan. Aksiologi sebagai dasar berarti bahwa pendidikan harus dapat menetapkan kriteria yang seharusnya ada tentang hubungan antara pendidikan dengaan nilai-nilai kemanusiaan yang ada. Nilai-nilai kemanusiaan itu mencakup nilai etika dan nilai keindahan. Dalam pendidikan, aksiologi sebagai dasar terkait dengan penerapan prinsip etika dan estetika dalam penelitian dan praktek pendidikan.

Secara khusus, ruang lingkup filsafat pendidikan uang menjadi objek filsafat pendidikan adalah meliputi kajian-kajian filosofis pendidikan sebagai berikut:

- Merumuskan hakekat pendidikan

- Merumuskan secara filosofis hakekat manusia yang berpartisipasi dalam proses pendidikan.

- Merumuskan secara filosofis hubungan antara filsafat, filsafat pendidikan, agama dan kebudayaan.

- Merumuskan hubungan antara filsafat, filsafat pendidikan dan teori pendidikan.

- Merumuskan hubungan antara filsafat negara, ideologi negara, filsafat pendidikan dan kebijakan pendidikan.

- Merumuskan sistem nilai, etika, dan moral sebagai isi pendidikan yang merupakan tujuan pendidikan.

Dengan demikian dari uraian tersebut diperoleh suatu kesimpulan bahwa yang menjadi objek filsafat pendidikan ialah semua aspek yang berkaitan dengan upaya manusia untuk mengerti dan memahami hakekat pendidikan itu sendiri, yang berhubungan dengan bagaimana pelaksanaan pendidikan dan bagaimana tujuan pendidikan itu dapat dicapai seperti yang diharapkan.

\section{Psikologi Pendidikan}

Psikologi adalah ilmu yang mempelajari dan menjelaskan fenomena mental dan perilaku manusia. Santrock (2010) menjelaskan bahwa psikologi pendidikan adalah cabang dari ilmu psikologi yang secara khusus mendeskripsikan, menganalisis, dan meramal proses pengajaran dan belajar dalam lingkungan pendidikan. Studi mengenai proses pembelajaran dan belajar, baik dari sudut pandang kognitif, afektif, maupun perilaku, memungkinkan ilmuwan psikologi pendidikan untuk memahami perbedaan individu dalam hal intelegensi, perkembangan kognitif, afek, motivasi, regulasi diri, konsep diri, akselerasi, perbedaan multikultural, dan 
efikasi diri dalam proses belajar mengajar dan pendidikan secara umum. Dalam psikologi pendidikan digunakan pendekatan penelitian yang komprehensif, yaitu metode kuantitatif, metode kualitatif, dan metode kritis,

Bidang dalam psikologi pendidikan meliputi studi tentang memori, proses konseptual, dan perbedaan individu (melalui psikologi kognitif) dalam mengkonseptualisasikan strategi baru mengenai proses belajar pada manusia. Psikologi pendidikan telah dikonstruksi atas dasar paradigma behavioristik, kognitif, humanistik, dan psikoanalisis.

\section{Psikologi Pendidikan Humanistik}

Psikologi pendidikan humanistik adalah aliran psikologi pendidikan yang terkonstruksi berdasar paradigma psikologi humanistik. Ini berarti psikologi pendidikan humanistik adalah psikologi pendidikan yang menerapkan prinsipprinsip dan teori-teori yang ada dalam psikologi humanistik ke dalam masalah-masalah pendidikan dan pengajaran. Tokoh-tokoh psikologi pendidikan humanistik adalah Carl Rogers dan Abraham Maslow yang berasal dari Amerika Serikat.

Psikologi humanistik merupakan suatu pendekatan psikologi yang memusatkan perhatian pada keunikan dan aktualisasi diri manusia. Aliran psikologi humanistik banyak memperoleh pengaruh dari aliran filsafat eksistensialisme, aliran filsafat humanism, dan aliran filsafat fenomenologi.

Psikologi humanistik sangat memperhatikan tentang dimensi manusia dalam berhubungan dengan lingkungannya secara manusiawi dengan menitik-beratkan pada kebebasan individu untuk mengungkapkan pendapat dan menentukan pilihannya, nilainilai, tanggung jawab personal, otonomi, tujuan dan pemaknaan hidup. Dalam hal ini, Bugenthal (1964) mengemukakan tentang 5 (lima) prinsip utama dari psikologi humanistik, yaitu:

- Keberadaan manusia tidak dapat direduksi ke dalam komponen-komponen

- Manusia memiliki keunikan tersendiri dalam berhubungan dengan manusia lainnya
- Manusia memiliki kesadaran akan dirinya dalam mengadakan hubungan dengan orang lain

- Manusia memiliki pilihan-pilihan dan dapat bertanggung jawab atas pilihanpilihanya

- Manusia memiliki kesadaran dan sengaja untuk mencari makna, nilai dan kreativitas

Prinsip-prinsip tersebut kemudian diterapkan dalam wilayah pendidikan sehingga membentuk manusia sebagai subjek yang unik dan mampu beraktualisasi diri seperti dikemukakan oleh tokoh psikologi humanistik yaitu Abraham Maslow.

\section{Filsafat Pendidikan Terhadap Psikologi Pendidikan Humanistik}

Perspektif filsafat pendidikan terhadap psikologi pendidikan humanistik dapat ditinjau dari tiga aspek kefilsafatan yang ada dalam pendidikan, yaitu dasar metafisika dalam pendidikan, dasar epistemologi dalam bidang pendidikan, dan dasar epistemologi dalam bidang pendidikan.

Secara ontologi dari sudut filsafat manusia psikologi pendidikan melihat manusia sebagai subjek pendidikan adalah memiliki potensi perkembangan diri (self growth) yang baik dan mampu untuk beraktualisasi diri. Potensi perkembangan diri itu perlu diaktualisasikan dalam proses pendidikan. Ini berarti secara ontologi kependidikan, psikologi pendidikan humanistik menjelaskan bahwa pendidikan adalah proses memanusiakan subjek didik atau peserta didik sebagai manusia yang memiliki potensi-potensi asli untuk mencapai aktualisasi diri.

Dasar epistemologi psikologi pendidikan dapat dilihat pada cara-cara pemerolehan pengetahuan dalam proses pendidikan. Secara khusus, pada cara-cara pemerolehan pengetahuan dalam proses pendidikan adalah mengarah pada metode pengajaran dan belajar dalam pendidikan. Secara epistemologi psikologi pendidikan humanistik cenderung mengarahkan metode pengajaran dan belajar berdasar prinsip-prinsip sebagai berikut:

- $\quad$ Pilihan bebas dalam diri peserta didik dan kontrol mandiri dalam belajar. Ini 
berarti guru hanya menjadi fasilitator dalam proses belajar mengajar.

- Interes siswa. Ini berarti dalam pengajaran dan belajar, siswa secara mandiri menentukan minat alam belajar mereka. Psikologi pendidikan humanistik menekankan pendidikan dan pengajaran yang berpusat pada anak (child centred education).

- Pribadi komprehensif. Dalam belajar, peserta didik melibatkan tidak hanya aspek kognitif tapi juga aspek perasaan (afektif).

- Evaluasi mandiri. Peserta didik melakukan evaluasi progres belajar secara mandiri terhadap segenap aktivitas belajarnya. Ini berarti dalam melakukan evaluasi belajar, psikologi pendidikan humanistik lebih menekankan pada evaluasi yang langsung berhubungan dengan pengalaman belajarnya atau sering disebut dengan istilah evaluasi otentik. Metode evaluasi ini menentang metode evaluasi yang terlalu menonjolkan pada tes-tes kognitif (memorisasi) yang mengabaikan aspek-aspek afektif.

- Guru sebagai fasilitator. Guru memiliki fungsi membantu dan mendampingi peserta didik mengembangkan potensi-potensi asli dalam dirinya.

Berdasar kajian epistemologi kependidikan di atas maka dasar epistemologi psikologi pendidikan humanistik adalah pluralistik (rasional, intuisionisme, dan fenomenologi). Rasional berarti pemerolehan pengetahuan berdasar pada akal, intuisi berarti pemerolehan pengetahuan berdasar pada olah rasa, dan fenomenologi berarti pemerolehan pengetahuan berdasar interaksi peserta didik dengan dunia gejala).

Berbeda dari psikologi pendidikan behavioristik yang cenderung memiliki pendekatan bebas nilai (value free approach), psikologi pendidikan humanistik memiliki pendapat bahwa proses pendidikan semestinya adalah lekat nilai atau terkandung nilai (value laden). Itu dapat dilihat bahwa dalam proses pendidikan, nilai-nilai yang diyakini oleh peserta didik dalam pendidikan berpusat pada anak ala pendidikan humanistik menjadi landasan utama dalam proses pendidikan.
Selama proses pendidikan, psikologi pendidikan humanistik menekankan pada nilai-nilai asli peserta didik sehingga mereka akan mampu mencapai perkembangan mandiri terkait penghargaan diri (self respect) dan kompetensi.

Dari penjabaran yang ada di atas dapat disimpulkan bahwa terdapat filsafat pendidikan dalam psikologi pendidikan humanistik. Filsafat pendidikan psikologi pendidikan humanistik adalah filsafat pendidikan yang memandang pendidikan sebagai proses memanusiakan peserta didik sehingga mampu berkembang dan beraktualisasi diri dengan segenap potensi asli yang ada dalam dirinya. Filsafat pendidikan tersebut telah memiliki dasar ontologi, epistemologi, dan aksiologi.

\section{KESIMPULAN}

Filsafat pendidikan psikologi pendidikan humanistik adalah filsafat pendidikan yang memandang pendidikan sebagai proses memanusiakan peserta didik sehingga mampu berkembang dan beraktualisasi diri dengan segenap potensi asli yang ada dalam dirinya. Perspektif filsafat pendidikan terhadap psikologi pendidikan humanistik dapat dilihat dari aspek ontologi pendidikan, epistemologi pendidikan, dan aksiologi pendidikan.

Dari sudut ontologi kependidikan, psikologi pendidikan humanistik menjelaskan bahwa pendidikan adalah proses memanusiaan subjek didik atau peserta didik sebagai manusia yang memiliki potensi-potensi baik untuk mencapai aktualisasi diri. Dasar epistemologi psikologi pendidikan humanistik adalah plural (rasional, intuisionisme, dan fenomenologi). Berbeda dari psikologi pendidikan behavioristik yang cenderung memiliki pendekatan bebas nilai (value free approach), psikologi pendidikan humanistik memiliki pendapat bahwa proses pendidikan semestinya adalah lekat nilai atau terkandung nilai (value laden).

\section{DAFTAR RUJUKAN}

Barnadib, Imam. 1994. Filsafat Pendidikan: Sistem dan Metode. Yogyakarta: Andi Offset.

Bugenthal, J. 1964. The Third Force in Psychology. Journal of Humanistic Psychology, 4 (1): 19-26. 
Fadhil Hikmawan, Perspektif Filsafat Pendidikan Terhadap Psikologi Pendidikan Humanistik|36

Hanurawan, F. 2012. Filsafat Ilmu Psikologi. Malang: BKP Universitas Negeri Malang.

Hanurawan, F., Syam, M., \& Samawi. 2006. Filsafat Pendidikan. Malang: FIP

Universitas Negeri Malang.
Saifulah, A. 1983. Antara Filsafat dan Pendidikan. Surabaya: Usaha Nasional. Santrock, John W. 2010. Psikologi Pendidikan. Jakarta: Kencana. 